\title{
Recovering Better from COVID-19 Will Need a Rethink of Multilateralism
}

\author{
Richard Kozul-Wright ${ }^{1}$
}

Published online: 6 November 2020

(c) Society for International Development 2020

\begin{abstract}
The world economy is experiencing a deep recession amid a still unchecked pandemic. But the commitment to recovering better will not materialize if, as happened after the global financial crisis, the advanced economies resort to a policy mix of austerity, liberalization and quantitative easing. Such an approach will only worsen a whole set of pre-existing conditions and in particular, high inequality, excessive debt (both public and private and weak investment-that will lead to a lost decade, particularly for developing countries. What is needed instead is an expansionary plan for global recovery, that can credibly return even the most vulnerable countries to a stronger position than before the crisis. This paper sets out some of the key elements of such a plan and argues that its implementation will require systematic reforms to the multilateral trade and financial system if a more resilient recovery is to turn into a sustainable and inclusive future.
\end{abstract}

Keywords Multilateralism $\cdot$ Economic recovery $\cdot$ New Deal $\cdot$ Hyperglobalization

The world economy is experiencing a deep recession amid a still unchecked pandemic. Now is the time to hammer out a plan for global recovery, one that can credibly return even the most vulnerable countries to a stronger position before the crisis. But we have been here before and to recover better this time will require abandoning some cherished principles that have (mis)guided policy making for the last several decades along with reforms to a multilateral system that has drifted away from its founding principles.

\section{Letting a Crisis go to Waste}

Back in 2009, leaders of the world's major economies vowed to recover better from the worst financial crisis since the Great Depression and struck a tone that suggested a readiness to recast the international order in a manner inspired by those who led the March out of war and ruin after 1945. The plan agreed at the G20 in London was bold ${ }^{1}$ : restore confidence, growth, and jobs; repair and reregulate the financial system; fund and reform international financial institutions

Richard Kozul-Wright

richard.kozul-wright@unctad.org

1 United Nations Conference on Trade and Development, Geneva, Switzerland to help overcome that crisis and prevent future ones; promote global trade and investment; and forge an inclusive, sustainable recovery.

It was, however, honoured more in the breach than the observance. Trillions of dollars went to repairing the financial system but with little serious reform allowing many of the practices and habits that had brought about the crisis to settle back in (Wolf 2014; White 2020). New trade agreements took shape but with no acknowledgement that previous agreements had contributed to a more unequal and fragile world (Rodrik 2018; Izurieta and Capaldo 2018; TDR 2019). And austerity soon captured the policy mindset, including in international financial institutions, on the false premise that cutting public spending and repressing wages would trigger a strong expansion (Breuer 2019; TDR 2020). The result was, instead, a self-reinforcing cycle of weak aggregate demand, widening inequality and tepid growth. In advanced economies, the average growth rate between 2010 and 2019 fluctuated around an annual average of $2 \%$, compared with $2.4 \%$ from 2001 to 2007 and $2.7 \%$ in the 1990 s. Growth declined for developing countries from $7.9 \%$ in 2010 to $3.5 \%$ in 2019, with an annual average of just $5.0 \%$ compared with $6.9 \%$ from 2001 to 2007 (or 3.4 and 4.9 respectively, excluding China).

\footnotetext{
${ }^{1}$ For the G20 London Summit statement https://www.imf.org/exter
} nal/np/sec/pr/2009/pdf/g20_040209.pdf. 
The recovery of jobs and labour incomes was particularly slow, which added to the weak recovery in demand and further depressed productivity growth. In many developing countries, high interest rates and overvalued currencies added to 'premature deindustrialization' pressures, growing labour market informality and a polarized economic structure (TDR 2017). It took a full decade for the global unemployment rate to return to the pre-crisis level but employment-to-population ratios, a better measure of labour market health, did not recover before the pandemic, neither in developed nor developing countries, with many prime-age workers dropping out altogether. Precarious labour contracts have risen sharply in both the North and South (ILO 2016).

Putting a cost on the great financial crisis is a difficult business; one estimate by the Federal Reserve Bank of Dallas puts the figure at between $\$ 6$ and $\$ 14$ trillion solely for the United States (Atkinson et al. 2013). Since then banks have become bigger than ever and the aptly labelled 'shadow banking system' has created an even more opaque financial system (Shaxson 2018; TDR 2019). Just how much risk has built up in the financial system over the last decade is difficult to tell but the massive rise of leveraged corporate loans was already spooking corporate bond markets before the pandemic hit (Aramonte and Avalos 2019; Çelik et al. 2019). There are growing concerns that the massive relief packages in response to the crisis will keep many large and destinedto-fail firms going, even as viable smaller businesses are starved of funds, again transferring dangerous risks from the private to the public balance sheet.

Developing country external debt also rose sharply during the last decade as global investors searched for high short-term returns in the context of near zero interest rates in the advanced economies following the GFC. Developing country external debt already more than doubled since 2008 to reach record levels of US\$ 10 trillion at end-2019, but the costs of servicing this debt also steadily increased with developing countries paying, on average, $14.6 \%$ of their export revenues and many countries well over a quarter of their government revenues to meet external debt obligations. UNCTAD (2020) estimates that developing countries face a wall of repayments on their external public and publicly guaranteed debt in the region of US\$2.7 trillion to US\$ 3.4 trillion in 2020 and 2021. At the same time, the ability of developing countries to self-insure against exogenous shocks and increased market risk through international reserve cushions had already weakened well before the current crisis, with the ratio of reserves to short-term external debt halving from its peak in 2009 at $544 \%$ to $279 \%$ in 2019 .

The hole in public finances caused by the financial crisis provided the justification for endless rounds of austerity on the false promise that cutting back government spending would release productive resources for the private sector and ignite growth. This has, no doubt, been one important factor in the lack of preparedness to the COVID-19 shock, particularly in the area of public health infrastructure. In the face of underfunded services, public private partnerships have been promoted as a new source of responsible finance, but with little or no supporting evidence that these actually deliver a more cost-effective service (Rowden 2019).

\section{The Multilateral Imperative}

Now another crisis, triggered by a microscopic pathogen, has exposed the fragility of today's interdependent world and forced advanced economies to again adopt massive relief packages, in the trillions of dollars, to stabilize corporate balance sheets and mitigate the damage to households from locking down. However, these same governments have been unwilling to extend a helping hand to developing countries where a combination of precarious work conditions, debt distress and insufficient fiscal and policy space have amplified the economic damage from the COVID-19 shock (TDR 2020).

While it has become popular to evoke the moniker of Roosevelt and the New Deal in the face of current fears and anxieties, there appears to be little appreciation of what he wanted from the multilateral system he helped to establish some 75 years ago. The intellectual foundations of the New Deal, from its inception, was based on two fundamental ideas. First, 'our mutual dependence one upon another-of individuals, of businesses, of industries, of towns, of villages of cities, of state, of nations' or what Roosevelt dubbed 'interdependence' (Rauchway 2018). This notion was a close cousin to the second big idea behind the New Deal, social justice, and mutual responsibility within nations. At Bretton Woods, Roosevelt made clear that these ideas were ripe for extension to the international level: 'Economic diseases' Roosevelt insisted, 'are highly communicable. It follows, therefore, that the economic health of every country is a proper matter of concern to all its neighbors, near and distant. Only through a dynamic and a soundly expanding world economy can the living standards of individual nations be advanced to levels which will permit a full realization of our hopes for the future'. ${ }^{2}$

In practice, multilateralism in the three decades after San Francisco never lived up to the ideals of the New Deal. Managed capitalism coexisted with a persistent and widening technological divide between North and South, wasteful military spending under a tense East-West divide with proxy wars crippled economic prospects in many developing regions, colonialism and lingering racial prejudice, unequal

\footnotetext{
2 https://www.cvce.eu/content/publication/2003/12/12/051f8 720-94b9-4aee-991b-901dd926a578/publishable_en.pdf.
} 
trade relations that inhibited productive diversification in many countries, and carbon-heavy growth that was heedless of the environmental cost.

Despite its faults, the core principles of Bretton Woods did, however, provide a rough template for a more balanced form of economic development in an interdependent world and provided a platform for a new generation of leaders from the South to break the bondages of colonialism and strive for a more inclusive international economic order. Those efforts ended with the economic dislocations and debt crises of the 1970s and early 1980s. Over the last four decades interdependence has given way to hyperglobalization as the guiding narrative of international relations, in which the territorial power of strong states has become intertwined with the extra-territorial power of footloose capital (TDR 2017, 2018). From the perspective of the less powerful, this state of affairs is more a mercantilist jungle than the open plains on which friendship, respect, justice and cooperation can flourish. Multilateralism has struggled to adapt and reforms, while regularly promised, have been resisted by the strongest players.

Despite the hopes of many developing countries now hanging in the balance, the inability of the international community to put forward comprehensive proposals to alleviate debt distress, inject emergency liquidity into the global economy or agree on an equitable distribution of any future vaccine are signs not only that policy-as-usual still prevails but that things could get worse.

If advanced country governments again opt for premature fiscal tightening in an attempt to bring down public debt and businesses adopt an aggressive cost-cutting strategy in an attempt to boost exports, recovery will fizzle out, with a double-dip recession likely in many countries in 2022, followed by a lost decade of slow growth, high unemployment and stagnant wages (TDR 2020).

\section{Recovering Better, Rebuilding Multilateralism}

An aborted economic recovery, or worse, another lost decade, is not preordained. It is a matter of policy choice. This time around advanced countries must choose and maintain an expansionary macroeconomic policy stance for as long as it takes the private sector to regain its confidence to spend. And while monetary policy is crucial, the battle of the moment is for governments to provide sufficient fiscal stimulus. Avoiding a lost decade will require governments to stick to deficit spending for several years ahead.

There is, however, more to recovering better than public spending. Raising productivity growth will require industrial and innovation policies and reversing wage repression. Stronger labour market institutions will be needed to align wages with productivity, support structural change and reduce inequality. Broader central bank mandates and tighter financial regulation will have to be put in place to tame speculative investment and channel credit to productive and necessary activities, from manufacturing medical equipment to production of renewable energy. Free trade agreements, the embodiment of neo-liberal thinking, deny these policy choices and must be avoided with roll back of existing agreements wherever appropriate and possible.

But even more than was the case 75 years ago, international cooperation and coordination are essential to fighting the pandemic and recovering better. So far, the timid and fragmented response of the international community has left many developing countries feeling helpless (and frustrated). While advanced countries are seeing the highest absolute falls in output for now (in some countries in double-digit figures in 2020), the greatest economic and social damage will be in developing countries, where, as noted above, levels of informality are high, health and social protection systems often weaker and commodities and tourism remain major sources of much needed foreign exchange. It is expected that between 90 and 120 million people will be pushed into extreme poverty in the developing world, with close to 300 million facing food insecurity.

This situation is even more critical given that the fiscal spaces of many developing countries have been squeezed by rising debt pressures which were already apparent prior to the pandemic. This is in part a consequence of the lopsided global recovery from the Global Financial Crisis but also of decades of premature capital account liberalization and financial deregulation that have turned developing country debt from a developmental policy tool into a speculative financial asset, with external borrowing relying more strongly on private, rather than bilateral and multilateral creditors. In this context, volatile investor sentiment, shortened maturities and greater rollover risks, in combination with high commodity price fluctuations have substantively increased debt and financial vulnerabilities.

The tools are available to provide fiscal space to developing countries; special drawing rights, dedicated financing windows and debt relief can all be quickly scaled up to mitigate the financial squeeze. But if this crisis is to offer a truly Rooseveltian moment of recovery and reconstruction then what is also required is a new set of principles for the global economy that can deliver prosperity for all and revive the health of a planet under increasing environmental stress.

The 'Geneva Principles for a Global Green New Deal' advances an urgent research and policy agenda for a New Multilateralism to calibrate the global economy toward a twenty-first century vision of stability, shared prosperity, and environmental sustainability (Gallagher and KozulWright 2019). Those Principles include 1. Global rules should be calibrated toward the overarching goals of social 
and economic stability, shared prosperity, and environmental sustainability and be protected against capture by the most powerful players 2. States share common but differentiated responsibilities in a multilateral system built to advance global public goods and protect the global commons 3 . The right of states to policy space to pursue national development strategies should be enshrined in global rules 4. Global regulations should be designed both to strengthen a dynamic international division of labour and to prevent destructive unilateral economic actions that prevent other nations from realizing common goals 5. Global public institutions must be accountable to their full membership, open to a diversity of viewpoints, cognizant of new voices, and have balanced dispute resolution systems.

These principles should be understood as a guide to policy initiatives that will be implemented by local and nationally accountable institutions, with the active participation of citizens and tailored to their particular circumstances, and as a working basis for collaboration at the international level in support of those initiatives. They suggest several areas of reform to the multilateral architecture that will be key to recovering better from COVID-19 and advancing a global green new deal.

Reining in corporate power is a prerequisite for recovering better. Anti-trust measures are now very much on the agenda at the national and regional levels. But existing multilateral agreements such as the UN`s Equitable Principles and Rules for the Control of Restrictive Business Practices adopted by the General Assembly in 1980, should be strengthened and operationalized with appropriate institutional support such as a global competition authority. Additional actions, made more urgent by the current crisis, regarding the price gauging, patent abuse and other anticompetitive practices of pharmaceutical giants and digital platforms, are warranted to ensure the recovery is both fair and resilient.

Clamping down on corporate tax avoidance and evasion and other forms of illicit financial flows can help both to expand fiscal space and address the inequality challenge. Recent estimates suggest that revenue losses, caused by tax-motivated illicit financial flows (IFFs) alone, are in the range of \$49-\$193 billion, accounting for 2.3\% of combined GDPs, respectively, in Latin America and the Caribbean and in Africa. Multilateral efforts towards reforming international corporate taxation require new energy, beginning with a much more concerted effort to clamp down on tax havens in the North, establishing a global asset registry to enable wealth taxes on the super-rich and moving to a unitary taxation system that recognizes that the profits of international corporations are generated collectively at the group level.

Sustainable financing will require vibrant public financing options. At the international level, that means boosting the lending capacity of multilateral development banks. This new lending could come from existing shareholders redirecting environmentally damaging subsidies, for example for fossil fuels and industrial agriculture, to the capital base of these institutions, or from more innovative sources, such as a financial transaction tax, and augmented by borrowing on international capital markets, with a measured relaxing of their fidelity to financial sobriety. In return, these institutions should reassess their policy conditionalities in line with a more sustainable and inclusive development agenda.

At the national and regional level, public and development banks also need more support, with governments wholehearted in their mandates and allowing their banks to lend beyond the extremely narrow parameters of triple-A ratings by the world's big rating agencies. The dual-sized role of credit rating agencies' as both player and umpire in the markets needs also to be revisited, given their impact on banks' abilities to raise capital for further lending.

A Marshall Plan for global health recovery could provide a more dedicated framework for building future resilience. But it should take its namesake seriously. In the first place that means being generous. If the donor community met the 0.7\% Official Development Assistance (ODA) target for the next 2 years that would generate something in the order of \$380bn above current commitments. An additional \$220bn mobilized by the network of multilateral and regional financing institutions could complete a $\$ 600 \mathrm{bn}$ support package over the next 18 to 20 months. The money should be dispersed largely as grants but with some room for zero interest loans, the precise mixture determined as the emergency response evolves. Finally, given the multifaceted nature of the recovery effort, a dedicated agency, drawing, like the Marshall Plan, on the personnel of existing agencies as well as from the private sector, with local expertise and coordination involved from the outset. Much like the original, a central financing and oversight agency linked to national public agencies through a regional coordination mechanism remains a model to follow.

Finally, a global sovereign debt authority, independent of either (institutional or private) creditor or debtor interests, should be established to address the manifold flaws in the current handling of sovereign debt restructurings. The COVID-19 crisis, and the stumbling efforts by the international community to agree emergency debt suspension and relief measures, have, yet again, put a glaring spotlight on the crippling fragmentation and complexity of existing procedures, the potentially extraordinary powers of hold-out creditors to sabotage restructurings, and the resultant inefficacy of crisis resolutions. At a minimum, such an authority should provide coherent frameworks and guidelines to facilitate automatic and comprehensive temporary standstills in recognized disaster situations, ensure that long-term developmental needs, including meeting the 2030 Agenda, are systematically taken into account in debt sustainability 
assessments, and provide an independent forum for expert advice to governments requesting this. In the longer run, it should provide a blueprint for a comprehensive reform of current sovereign debt workout mechanisms to balance creditor and debtor interests fairly, close loopholes for holdout creditors, and prioritize the long-term collective interests of the many over the short-term financial rewards of the few.

\section{References}

Aramonte, Sirio, and Fernando Avalos. 2019. Structured finance then and now: A comparison of CDOs and CLOs, BIS Quarterly Review, 22 September.

Atkinson, Tyler, David Luttrell and Harvey Rosenblum. 2013. How Bad Was It? The Costs and Consequences of the 2007-2009 Financial Crisis, Dallas fed, Staff Papers, no. 20, July.

Breuer, Christian. 2019. Expansionary Austerity and Reverse Causality: A Critique of the Conventional Approach, INET Working Paper No. 98, Institute for New Economic Thinking.

Çelik, S., G. Demirtaş, and Mats Isaksson. 2019. Corporate Bond Markets in a Time of Unconventional Monetary Policy. OECD Capital Market Series. Paris. http://www.oecd.org/corporate/corporatebond-markets-in-a-time-of-unconventional-monetary-policy.htm.

Gallagher, Kevin P., and Richard Kozul-Wright. 2019. A New Multilateralism for Shared Prosperity: Geneva Principles for a Global Green New Deal, UNCTAD/Boston University, April.

ILO. 2016. Non-Standard Employment Around the World. Geneva: International Labour Office.

Izurieta, Alex, and Jeronim Capaldo. 2018. Macroeconomic effects of 21 st Century trade and investment agreements: The case of the Trans-Pacific Partnership. Development and Change 49(4): 951-977.

Rauchway, Eric. 2018. Winter War: Hoover, Roosevelt, and the First Clash Over the New Deal. New York: Basic Books.
Rodrik, Dani. 2018. What Do Trade Agreements Really Do? National Bureau of Economic Research, Working Paper No. 24344, February.

Rowden, Rick. 2019. From the Washington Consensus to the Wall Street Consensus The financialization initiative of the World Bank and multilateral development banks. Washington, DC: Heinrich Boll Stiftung.

Shaxson, Nicholas. 2018. The Finance Curse: How Global Finance Is Making Us All Poorer, Bodley Head.

TDR. 2017. Trade and Development Report, 2017: Beyond Austerity-Towards a Global New Deal. New York and Geneva: United Nations publication. Sales No. E.17. II.D.5.

TDR. 2018. Trade and Development Report, 2018: Power, Platforms and the Free Trade Delusion. New York and Geneva: United Nations publication. Sales No. E.18. II.D.7.

TDR. 2019. Trade and Development Report, 2019: Financing a Global Green New Deal. Geneva: United Nations publication. Sales No. E.19.II.D.15.

TDR. 2020. From global pandemic to prosperity for all: avoiding another lost decade, Geneva: United Nations publication. Sales No. E.20.II.D.30.

UNCTAD. 2020. From the Great Lockdown to the Great Meltdown: Developing Country Debt in the Time of Covid-19, UNCTAD/ GDS/INF/2020/3, April, Geneva.

Wolf, Martin. 2014. The shifts and the Shocks: What We've Learned: and Have Still to Learn-from the Financial crisis, Allen Lane.

White, William. 2020. International Financial Regulation: Why It Still Falls Short, INET Working Paper No. 131, Institute for New Economic Thinking.

Publisher's Note Springer Nature remains neutral with regard to jurisdictional claims in published maps and institutional affiliations. 